\title{
DIVERSITY-DOMINANCE AND SUCCESSION OF FUNGAL COMMUNITIES IN SANDY SOILS (A BEACH OF V REGION - CHILE) ON KERATINIC SUBSTRATA. I.
}

\author{
*EDUARDO PIONTELLI L. *M. ALICIA TORO S.M. \\ **DUNNY CASANOVA Z. \\ Universidad de Valparaiso. Escuela de Medicina \\ * Cáted ra de Micología. \\ ** Cátedra de Salud Pública. \\ Casilla 92 V - Valparaíso. Chile
}

\section{SUMMARY}

With the purpose of demonstrating the survival of pathogenic or potentially pathogenic fungiof sands collected from marine public beaches, a source of information of ecological interest and related to Public Health, we tracked saprophyte growth of keratinophilic-lytic fungal communities in keratinic substrata of a beach in Viña del Mar (Caleta Abarca) by means of a monthly sampling from January through December 1982 .

Using the hair bait technique, 92 species were isolated which, after application of a mathematical coefficient of abundance became classified as Dominant (3,3\%) ). Accesory (8,7\%) and Accidental $188,3 \%)$. highest levels were recorded in genera Aspergillus, Penicillium and Acremonium.

Greatest similarities of mycota (Winner's coefficient) took place from May through Aitgust (Winter) and from January through April (Summer-Autumn) whereas highest values of diversity (Shannon's coefficient) occurred from July through October (Winterearly in Spring).

Overall pattern of colonization of keratinic substratum (human hair) reveals that most of fungal communities recorded as primary colonizers are nonkeratinolytic fungi that take advantage of simple portion of substratum. Highest frequency-occurring group lover 50\% / was recorded, in a decreasing order, among genera A spergillus, Penicillium, Ochroconis and Botryotrichum.

A minority made up by keratinolytic fungi themselves, among which are genera Chrysosporium, Trichophyton and Scopulariopsis represent main secondary colonizers, making their appearance as a steady group in all beach areas.

Microsporum gypseum and Trichophyton mentagrophytes were the pathogenic dematophytes isolated. Possibility of sunival of these keratinolytic fungi along with a considerable number of fungi assumed as opportunist such as Aspergillus fumigatus, A. niger, A. terreus, Acremonium kiliense, Fusarium oxysporum, Mucor racemosus, Scopulariopsis brevicaulis, $S$. brumptii among others. corroborates that public beaches very much crowded by people are places to be considered in transmission of certain mycoses.

\section{RESUMEN}

[Diversidad-dominancia y sucesión de comunidades fúngicas aisladas en suelos arenosos (una playa de la $V$ Región. Chile) sobre anzuelo queratínico. $I$. I

Con la finalidad de demostrar la sobrevivencia de hongos patógenos o potencialmente patógenos en las arenas de playas recreacionales marinas, información de interés ecológico y relacionada a Salud Pública, pesquizamos el crecimiento saprófito de las comunidades fungicas queratinofilicas-liticas en substratos queratinicos en una playa de Viña del Mar (Caleto Abarca), mediante un muestreo mensual entre los meses de Enero a Diciembre de 1982.

Con la técnica del anzuelo queratinico se aislaron 92 especies, las cuales mediante la aplicación de un indice matemático de abundancia ocuparon las categorias de Dominantes (3,3\%), Accesorias $\{8,7 \%$ ) y Accidentales $(88,3 \%)$. Los indices más altos correspondieron a los géneros Aspergillus, Penicillium y Acremonium.

Las mayores similitudes de la micota (indice de Winner) se presentaron desde Mayo a Agosto (Invierno), y Enero a Abril (Verano-Otoño), y los mayores valores de diversidad (indice de Shannon), entre Julio y Octubre (Inviemo-principios de Primavera).

El modelo general de colonización del substrato queratinico (pelo humano), demuestra que la mayoria de las comunidades füngicas registradas como colonizadores primarios, son hongos no queratinoliticos que aprovechan la parte simple del substrato. Los de más alta frecuencia (sobre el $50 \%$ / correspondieron en onden decreciente a los géneros Aspergillus, Penicillium, Acremonium, Ochroconis y Botrytrichum. Una minoria integradá por hongos queratinoliticos propiamente tales, entre ellos los géneros Chrysosporium, Trichophyton y Scopulariopsis, son los principales colonizadores secundarios, presentándose como un grupo constante en todos los sectores de la play'a.

Microsporum gypseum y Trichophyton mentagrophytes, fueron los dermatofitos patógenos aislados. la posibilidad de sobrevivencia de estos queratinoliticos junto a un buen numero de hongos considerados como "oportunistas", tal como Aspergillus fumigatus, A. niger, A. terreus, Acremonium kiliense, Fusarium oxysporum, Mucor racemosus, Scopulariopsis brevicaulis, $S$. brumptii entre otros, confirma que las playas recreacionales de alta concurrencia, son lugares que deben considerarse en la transmision de ciertas micosis. 


\section{INTRODUCTION}

Occurrence of fungal communities in waters adyacent to marine shores and especially in public beaches has been studied considering that these natural habitats are fit for fungal survival.

At present epidemical and ecological investigations aim to the finding of those agents responsible for the transmission of human and animal mycoses with the clear purpose of examining their terrestrial environment, attempting to intercorrelate climate edaphic and flora-flauna factors. Boundaries of these environments become ultimately mixed together with marine, lake and river coast lines resulting in a clear overlapping of environment under certain circumstances. This is especially true in the case of marine beaches where waves totally or partially wash these places intended for entertaiment and swimming of the surrounding population and which to some extent favor the transmission route of soil or water fungal species to man or viceversa, thus making up one of the many reservoirs of mycological interest. There are many studies carried on filamentous and yeast-like, pathogenic or "opportunist" fungi isolated from public beaches and coast line marine waters: Kishimoto and Baker 1969; Dabrowa at al. 1964; Beneke and Rogers, 1970; Boiron and Agis, 1982; Boiron et al. 1983; Baylet et al. 1981; Caretta 1978; Purchio et al. 1979; Todaro 1978 (a.b).

Fungi existing on keratinized tissues were referred to at' the beginning as keratinophilic (de Vries 1962) but according to Dominik et al (1973), a marked distinction must be made among those which are in fact capable of degrading substrate from the ones which in spite of settling on the same source in nature make only use of the associated substances such as intercellular cements, protoplasmal sediments or some derivative of its partial degradation. The latter authors suggest to designate keratinolytic to fungi mentioned firstly and keratinophilic to those mentioned secondly.

This distinction setting up a clear concept cannot be applied yet in a general sense until we have a sound knowledge not only of the occurrence of colonies on hairs, feathers or other keratinized sources but also of their actual keratinolytic properties (Filipello and Mosca 1980-81, 1982).

We cannot exclude the role played in contamination by yeast-like populations and colonies that combined with bacteria are contributed by rivers, streams and estuaries added with organic matter resulting from human activity that ultimately are an integral part of microbiota of sands in those places where these sources of water flow out on their way to the sea. The constant occurrence of these microorganisms is presently taken as a potential sign of contamination of this environment, Cooke et al. 1960; Simard 1971; Scherry et al. 1979; Paula C. et al. 1983.

The objectives of our investigation are: a) to track on the sands of a beach in Viña del Mar
(Chile) keratinophilic-keratinolytic filamentous fungi with their propagule on a keratinized bait, b) to make oneself acquainted with potentially pathogenic fungal species having this particular ecological environment as their habitat.

\section{MATERIALS AND METHODS}

During the period from January 82 up to December 82 , forty four surface samples $(5 \mathrm{~cm}$ depth) of sand recovered from the public beach Caleta Abarca in Viña del Mar were examined. Twenty two of them are from the intertidal zone (wet) (I), corresponding to the area washed by waves and twenty two samples are from the dry zone (D) behind the former, up to the gravity retaining wall. The beach, about 200 metre long, was divided into four sections which were about 50 metre apart in both I and D zones. In each of the eight sections (4 I and 4 D), four samples were selected at random which ultimately became mixed in an overall pool per zone in such a manner that they would spread evenly in two sampling I and D units. This operation was carried out once to twice a month during the period already mentioned. February and July were the only months with only one sample.

The two sampling units resulting after each recovery were taken to the laboratory for their processing within a $24--48$ time period, being kept refrigerated in the meantime.

I and D samples were divided into equal parts and they were applied different isolation techniques $(A, B)$ in order to detet the presence of fungi.

A) Isolation of keratinophilic-keratinolytic fung: By means of Vanbreuseghem technique (1952), part of I and D sand was placed on sterile plates (four samples for I and four for D), which were added with sterile human hair cut into 1 to $2 \mathrm{~cm}$ little pieces. Plates were moistened with a chloramphenicol-added distilled water solution $(0.5 \mathrm{~g} / \mathrm{lt})$.

Then they were incubate at room temperature for a 75-day time period and later on examined under a stereoscopic magnifying gass every two days until the appearance' of the first fungi. Afterwards at 5-day intervals in order to assess fungal growth and propagule.

Existing fungi were isolated in different culture media such as Corn Meal Agar (CMA), Potato Carrot agar (PZA) added with $1 / 000$ yeast extract, Malt Agar (AM) and Czapek agar (CA).

B) Estimative count of filamentous fungi. The standarized Fred and Waksman (1928) plate dilution method was used. With part of sand from I and D zone, a base suspension containing $50 \mathrm{~g}$. sand in $50 \mathrm{ml}$. sterile seawater was prepared.

This mixture was shaked for 30 minutes in a mechanical shaker at 150 rotations per minute. One $\mathrm{ml}$. was removed from these suspensions and added to a test tube containing $9 \mathrm{ml}$ sterile seawater thus 
obtaining the first dilution $\left(10^{1}\right)$ and from then on up to $10^{3}$.

One $\mathrm{ml}$ of each dilution ( $\mathrm{I}$ and $\mathrm{D}$ ) was introduced on three $12-\mathrm{cm}$ diameter sterile petri dishes adding $18 \mathrm{ml}$. Corn Meal Agar previously liquified at $45^{\circ} \mathrm{C}$. This same operation was carried out in Malt Agar. All dishes were incubated at $25^{\circ}$ for seven days.

Coefficients and criteria used in analysis of results obtained by hair bait technique (H.B.)

1.- As an indication of abundance for each species, the following parameter was used:

$A=\frac{1}{m} \sum_{j=1}^{m} f j$

where $m=$ number of samples collected in a 2-month period.

$f \mathrm{j}=$ frequency value assigned for the presence of the species on a sample.

Frequency values used in this paper were: 1 , representing a minimum frequency (only in one plate), 2, an intermediate frequency (in two or three plates) and 3, a high frequency of colonies (in four plates). Maximum value of this parameter is 3 when there is a maximum frequency on the $\mathrm{m}$ samples. Minimum value is $1 / \mathrm{m}$ when there is a minimum frequency in only one of the samples examined.

2.- As an indicator of similarity of presence between two lists of species, Jaccard's method was used:

$S=\frac{C}{A+B-C}$

where $\mathrm{A} \doteq$ number of species present in list 1 $\mathrm{B}=$ number of species present in list 2 $C=$ number of species in common to both lists

3.- As an indicator measure of similarity in abundance of species between two lists, Winner's method was used:

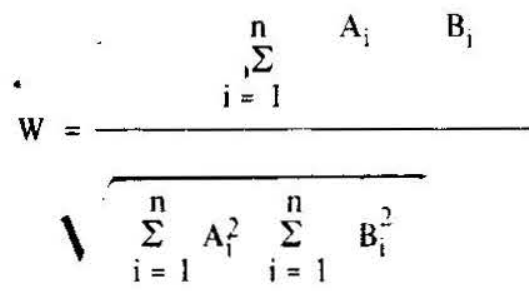

where: $\mathbf{A}_{\mathrm{i}}=$ value of abundance of specie: $\mathrm{i}$ in list $\mathbf{1}$
$\mathrm{B}_{i}=$ value of abundance of specie, $i$ in list 2 two lists.

$n=$ number of species present in either of the

4.- As a coefficient of diversity, Shannon's specific diversity indicator was used to get a list of species:

$D=-\sum_{i=1}^{n} \frac{A_{i}}{N} \log \frac{A_{i}}{N}$

where: $A_{i}=$ value of abundance of species $i$ in a list $N=\sum_{i=1}^{n} \quad A_{i}$

$\mathrm{n}=$ number of species present in the list.

5.- In order to characterize a species in terms of "dominance", its "relative abundance number" $\Lambda R=\left(A_{i} / \sum_{i=1}^{n} A_{i}\right) \cdot 100$ was calculated and the following scale was used:

Accidental (a), if $A R \leqslant 2 \%$

Accesory (A), if $2,1 \% \leqslant \mathrm{AR} \leqslant 5 \%$

Dominant (D), if $A R \geqslant 5.1 \%$

6.- In order to characterize a species in terms of "transitory presence" the following scale was used: (which is valid for both techniques, H.B. and D.P.).

Sporadic (e), if species was present in one or two $2 \cdot$ month duration periods.

Frequent $(F)$, if it was present in three or four 2-month duration periods.

Constant (C), if it was present in five or six 2 -month duration periods.

\section{RESULTS AND DISCUSSION}

During the period January through December 1982 in Caleta Abarca beach of Viña del Mar in the study areas and in both zones (I. D.), 107 fungal species were isolated corresponding to 46 genera, $86 \%$ of them being isolated by the hair bait technique (Table 1). By using the abundance percentage it was noted that $3,3 \%$ of the 92 species isolated by this technique was present as dominant, $8.7 \%$ as accesory and the remaining $88.3 \%$ as accidental (Table 1), a distribution having a specific diversity of 5.69 bits.

In a dry zone, 88 out of those 92 species were isolated $(95.6 \%)$ while in an intertidal zone only $43(46.7 \%)$. In the former distribution was $2.3 \% ; 14.8 \%$ and $81.8 \%$ for dominant, accesory an accidental species, respectively with a diversity factor of 6.50 bits, whereas in the lat ter, distribution was $70 \%, 20,9 \%$ and $72.1 \%$ respectively, with a diversity factor of 4.59 bits. 


\section{TABLE 1}

General list of species (separated anamorph and teleomorph entities) isolated by keratinized bait (H.B.) and dilution plating (D.P.). Abundance standards per two-month duration periods (only H.B.) and transitory presence

\begin{tabular}{|c|c|c|c|c|c|c|c|}
\hline & & & & & & & $\begin{array}{l}\text { Transitory } \\
\text { presence }\end{array}$ \\
\hline & & & & & & & Techniques \\
\hline FUNGI & $J-F$ & $\mathbf{M}-\mathbf{A}$ & $M-J$ & $\mathbf{J}-\mathbf{A}$ & S-O & $\mathrm{N}-\mathrm{D}$ & H.B. D.P. \\
\hline
\end{tabular}

Acremonium breve (Sukap, \& Thirum.) W.Gams

Acremonium kiliense Grütz

Acremonium potronii Vuillemin

Acremonium roseogriseum (S.B.Saksena)W.Gams

Acremonium strictum W. Gams

Acremonium terricola (Miller \& col.) W. Gams

Alternaria alternata (Fr.) Keissler

Alternaria plurisepta (Karst. \& Har.) Jorstad

* Aphanoascus fulvescens (Cooke) Apinis

* Aphanoascus terreus (Randhawa \& Sandhu) Apinis

* Arthroderma quadrifidum Dawson \& Gentles Aspergillus candidus Link ex Fries

Aspergillus fumigatus Fresenius

Aspergillus niger van Tieghem

Aspergillus ornatus Raper,Fennell \& Tresner

Aspergillus ochraceous Wilhelm

Aspergillus puniceus Kwon \& Fennell

Aspergillus repens (Corda) de Bary

Aspergillus sydowii (Bain \& Sart.) Thom \&

Church

Aspergillus terreus Thom

Aspergillus ustus (Bain) Thom \& Church

Aspergillus versicolor (Vuill.) Tiraboschi

Aureobasidium pullulans (de Bary) A rnaud

Beauveria bassiana (Bals.) Vuillemin

Botrytis cinerea Pers. ex Nocca \& Balb.

Botryotrichum piluliferum Sacc. \& March.

Circinella mucoroides Saito

Circinella muscae (Sorokine) Berlese \& DeToni

Chaetomium dolichotrichum Ames

Chaetomium elatum Kunze ex Steud

Chaetomįum globosum Kunze ex Steud.

Chaetomium murorum Corda

* Chrysosporium anamorph of Arthoroderma cuniculi Dawson

* Chry sosporium indicum (Randhawa \& Sandhu) Garg

* Chrysosporium keratinophilum D. Frey ex Carmichael
1.1251 .40

0.125

0.500

0.30

$\begin{array}{ll}0.750 & 0.10\end{array}$

$0.125 \quad 0.10$

0,375

0.625

0.125

0.10

0.40

$0.33 \quad 1.38$

0.17

$0.125 \quad 0.20$

0.250

0.10

$0.250 \quad 0.10$

0.20

$1.000 \quad 0.40$

0.67

0.75

1.33

1.50

$0.13 \quad 0.33$

0.13

0.50

0.75

0.50

0.83

0.50

0.17

0.33

0.50

0.25

$-$

0.50

0.17

0.13

0.17

0.17

0.38

0.67

0.17

0.83

0.125

0.38

0.17

0.125

0.90

0.67

0.38

$2.125 \quad 180$
0.625

0.83

0.88

1.50

1.17

1.50

0.625

0.70

0.17

0.88

0.17

$0.375 \quad 1.00$

0.13

0.50

0.25

0.67 ;

0.17

0.25

0.50

0.10

0.38

$\begin{array}{ll}0.17 & 0.25\end{array}$

0.13

0.20
0.70

0.375

0.17

0.30

0.25

0.50

0.17

0.50

$\begin{array}{ll}\text { C } & \text { C } \\ \text { e } & \\ \text { C } & \text { C } \\ \text { e } & - \\ \text { F } & \text { e } \\ \text { F } & \text { e } \\ \text { C } & \text { e } \\ \text { C } & \text { e } \\ \text { F } & -\end{array}$

* Keratinoly tic species 
* Chrysosporium merdarium (Link ex Grev.)

Carmichael

* Chrysosporium pannicola (Corda) van Oorschot \& Stalpers

* Chrysosporium tropicum Carmichael

Cladosporium acaciicola M.B. Ellis

Cladosporium cladosporioides (Fres.) de V ries

Cladosporium herbarum (Pers.) Link ex S.F. Gray

Drechslera dematioidea (Bubák \& Wróblewski)

Subram.\& Jain.

Doratomyces stemonitis (Pers. ex Fr.) Morton

\& Smith

Epicoccum purpurascens Ehrenb. ex Schlecht.

Fusarium equiseti (Corda) Sacc.

Fusarium oxysporum Schlecht

Gliocladium catenulatum Gilm. \& Abbott

Gliocladium roseum Bain

Gliomastix cerealis (Karst) Dickinson

Gliomastix murorum (Corda) Hughes

Giomastix murorum (Corda) Hughes var.

polychroma (van Beyma) Dickinson

* Gymnoascus siglerae v. Arx

Isaria sp.

* Keratinomyces ajelloi Vanbreuseghem

* Malbranchea dentritica Sigler \& Carmichael

* Microsporum gy pseum-fulvum (complex) Uriburu

Monodictys paradoxa (Corda) Hughes

Manocillium indicum S.B. Saksena

Mucor abundans Povah

Mucor fragilis Bainer

Mucor hiemalis Wehmer

Mucor lamprosponus Lendner

Mucor rouxianus (Calmette) Wehmer

Myceliophthora vellerea (Sacc. \& Speg.) van

Oorschot

Mycelia without fructifications

Neosartorya fischeri (Wehmer) Malloch \& Cain

Ochroconis tshawytschae (Doty \& Slater)

- Kirilenco \& All-Achmed

Oedocephalum roseum Cook

* Paecilomyces lilacinus (Thom) Samson

Paecilomyces sp.

Papulaspora immersa Hotson

Papulaspora sp.

Penicillium adametzi Zaleski

Penicillium aurantiogriseum Dierckx
0.20

$\begin{array}{cccccccc}0.125 & & 0.17 & 0.38 & 0.83 & 0.83 & \mathrm{C} & - \\ 0.50 & & & & 0.50 & 0.33 & \mathrm{~F} & - \\ & & & & 0.67 & & \mathrm{e} & \mathrm{e} \\ 0.50 & 0.40 & 0.67 & 0.63 & 0.50 & 0.33 & \mathrm{C} & \mathrm{C} \\ & & & & & & - & \mathrm{e} \\ & & & & & & & \\ 0.38 & 0.10 & & & 0.33 & & \text { F } & \text { e }\end{array}$

0.10

0.13

0.13

0.13

0.38

0.50

0.50

0.17

$0.10 \quad 0.50$

0.17

0.17

0.17

$0.17 \quad 0.33$

0.25

0.33

0.17

$0.13 \quad 0.30$

\section{$0.17 \cdot 0.38$}

0.50

0.17

0.13

.25

0.20

0.33

0.13

0.17

0.17

0.33

0.30

0.17

0.25

0.13

0.13

$0.17 \quad 0.50$

0.17

0.10

$1.00 \quad 1.40$

0.67

0.38

$2.17 \quad 1.17$

C

e
C
F
e
e
e
F

c

e

e

e

.00

C

e

e

e

C

e

D.


Transitory

presence

Penicillium brevicompactum Dierckx

Penicillium citrinum Thom

Penicillium chrysogenum Thom

Penicillium cyaneofulvum Biourge

Penicillium decumbens Thom

Penicillium digitatum (Pers. ex St. Am.) Sacc.

Penicillium echinulatum Raper \& Thom

ex Fassatiová

Penicillium expansum Link ex Gray

Penicillium fellutanum Biourge

Penicillium jensenii Zaleski

Penicillium lanosum Westling

Penicillium lapidosum Raper \& Fennell

Penicillium rubrum Stoll.

Penicillium spinulosum Thom

Penicillium urticae Bainier

Penicillium sp.

Phoma herbarum Westend

Phoma sp.

Rhizopus microsporus v. Tiegh. var.

chinensis (Saito) Schipper \& Stalpers

Rhizopus stolonifer (Ehrenb. ex Link) Lind

* Scopulariopsis brevicaulis (Sacc.) Bain

* Scopulariopsis brumptii Salvanet-Duval

Scopulariopsis candida (Gueguén) Vuillemin

Scopulariopsis chartarum (G. Sm.) Morton

\& G.Sm.

Sepedonium chrysospermum (Bull.) Link ex Fr.

Stachybotrys atra Corda

Stemphylium state of Pleospora herbarum

(Pers ex Fr.) Rabenh.

Scytalidium lignicola Pesante

Torula sp.

Trichoderma aureoviride Rifai

Trichoderma harzianum Rifai

Trichoderma koningii Oudem.

Trichoderma viride Pers ex Gray

* Trichophyton mentagrophytes (Robin) Blanchard var. mentagrophytes

* Trichophyton terrestre, Durie \& D. Frey

complex

Ulocladiun atrum Preuss

Ulocladium botrytis Preuss

Ulocladium chartarum (Preuss) Simmons

Verticillium lamellicola (F.E.V.Smith)

W. Gams

Verticillium lateritium (Ehrenberg) Rabenhorst
0.13

\begin{tabular}{|c|c|c|c|c|c|c|c|}
\hline & &.- & . & - & - & - & e \\
\hline & & & 1.38 & 1.00 & & $\mathrm{e}$ & $\mathrm{e}$ \\
\hline & 0.30 & & 0.13 & 0.17 & & F & e \\
\hline & & & 0.13 & 0.83 & 0.17 & F & $F$ \\
\hline & -. & - & - & - & - & - & $\mathrm{e}$ \\
\hline & & & & 0.17 & 0.17 & e & e \\
\hline - & - & - & $\ldots$ & - & - & - & $\mathrm{e}$ \\
\hline & & & 0.13 & & & e & - \\
\hline & - & - & & - & - & $\cdots$ & $\mathrm{e}$ \\
\hline 0.38 & 0.40 & 0.17 & & & & $\mathrm{~F}$ & C \\
\hline 0.50 & 0.70 & 0.33 & 1.00 & 0.17 & 0.33 & C & C \\
\hline & -. & -- & - & - & - & - & $\mathrm{e}$ \\
\hline 0.25 & & & & & & e & e \\
\hline 2.00 & 1.30 & 1.00 & 1.63 & 2.00 & 1.17 & C & C \\
\hline- & -. & & -- & 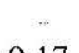 & $=$ & - & e \\
\hline & & & & 0.17 & 0.50 & e & - \\
\hline & & & & 0.17 & 0.33 & e & e \\
\hline & & 0.17 & 0.13 & 0.50 & 0.33 & $F$ & $\mathrm{e}$ \\
\hline & $\therefore$ & & - & - & - & - & e \\
\hline & $\ldots$ & & - & - & - & - & e \\
\hline & 0.10 & & & 0.17 & 0.33 & $F$ & e \\
\hline & 0.20 & & & & & e & - \\
\hline & & & & - & 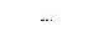 & - & e \\
\hline & & & & 0.33 & 0.17 & e & - \\
\hline & & 0.17 & 0.25 & & 0.17 & $\mathrm{~F}$ & - \\
\hline & & & 0.38 & 0.67 & 0.33 & $\mathrm{~F}$ & $\mathrm{e}$ \\
\hline 0.13 & & & 0.13 & 0.33 & 0.17 & $\mathrm{~F}$ & - \\
\hline & & & & 0.17 & & $\mathrm{e}$ & \\
\hline & 0.10 & & & & & $\mathrm{e}$ & - \\
\hline & & & & 0.17 & 0.33 & e & $\mathrm{e}$ \\
\hline 0.38 & & & 0.38 & & & $\mathrm{e}$ & $\mathrm{e}$ \\
\hline 0.25 & & & 0.13 & & 0.17 & $\mathrm{~F}$ & F \\
\hline & & & & 0.33 & 0.33 & e & - \\
\hline
\end{tabular}

0.25

0.50

$\begin{array}{lll}0.50 & 0.63\end{array}$

$\begin{array}{ll}0.50 & 0.75\end{array}$

0.25

$0.13 \quad 0.40$

0.13

$0.67 \quad 0.50$

0.17

0.25

0.10

e

F

F

F

0.50 
This reveals that in a dry zone there is a greater equilibrium of the mycota than in the intertidal zone.

Highest values in increased numbers of species throughout the period examined were observed in species of genera Aspergillus, Penicillium and Acremonium, both at a total level as well as in each of the study areas which points out the significance of these genera in marine public beaches, a fact that is not surprising for us since the presence of these Eurotiaceas has been reported and emphatized by several investigators: Kishimoto and Baker 1969; Mustafá and Al Musalem 1975; Todaro 1978b; Criseo et al. 1982; Esterre and Agis 1983.

With reference to number of species during the 12-month period we could observe the highest relative abundance in September through October (Spring) and the lowest in May through June (Winter), keeping constant the rest of the year. The same peak can be seen separately in each sampled zone (Diagram 1).

DIAGRAM 1. Average of species abundance isolated on hair bait, overall and per zone.January-December 1982

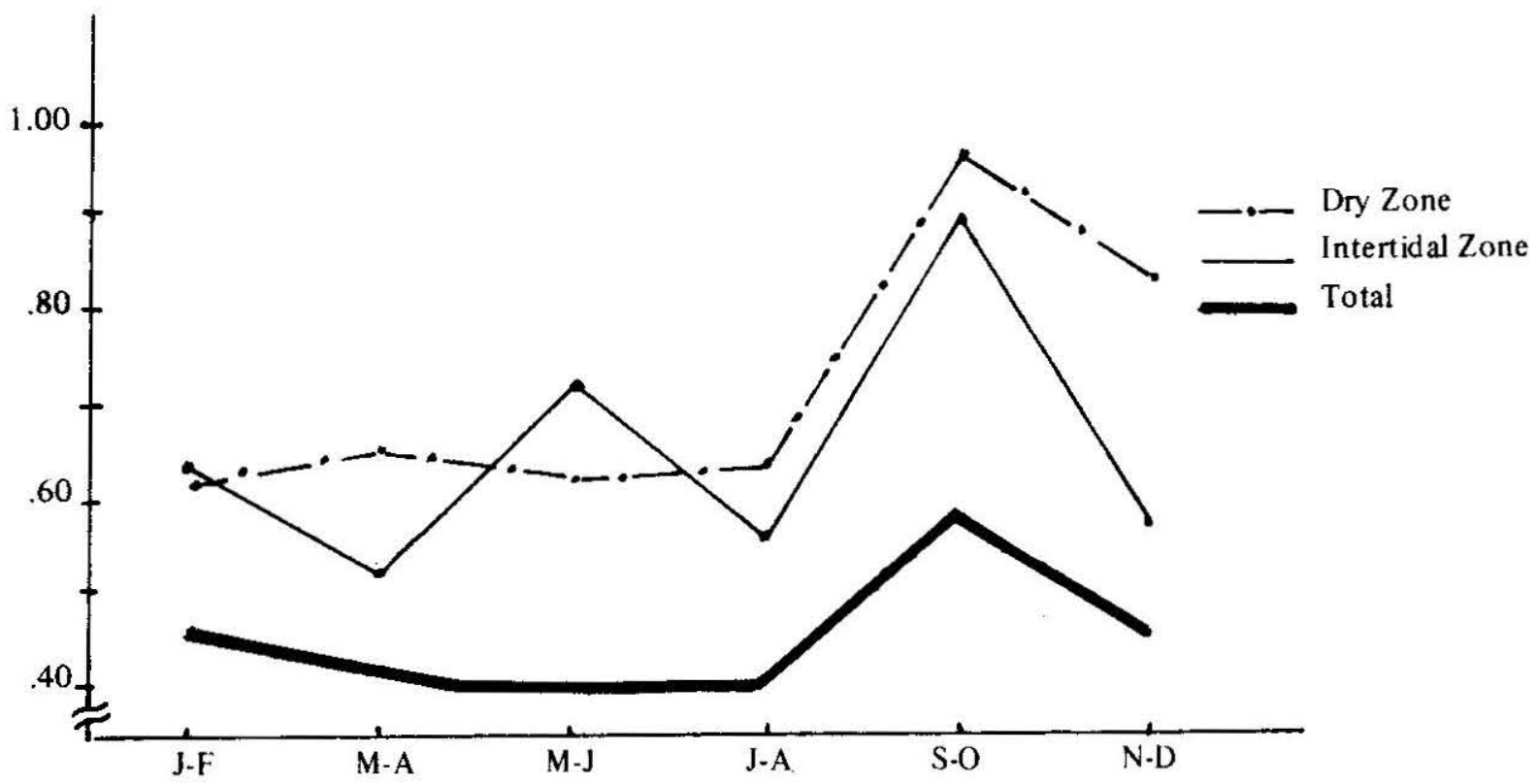

The greatest similarities in isolated taxa are seen between the two 2-month duration periods of Winter; from May through August and between Summer and Autumn; from January through April (Table 2)

\section{TABLE 2}

Similarities (Winner) among two-month duration periods in both zones

\begin{tabular}{|c|c|c|c|c|c|}
\hline & M-A & $M-J$ & $\mathrm{~J}-\mathrm{A}$ & S-O & $\mathrm{N}-\mathrm{D}$ \\
\hline $\mathrm{J}-\mathrm{F}$ & .854 & .709 & .658 & .728 & .664 \\
\hline$\overline{\mathrm{M}-\mathrm{A}}$ & & .142 & .192 & .135 & .463 \\
\hline $\mathrm{My}-\mathrm{J}$ & & & .948 & .293 & 695 \\
\hline $\mathbf{J}-\mathbf{A}$ & & & & .022 & .161 \\
\hline $\mathrm{S}-\mathrm{O}$ & & & & & .161 \\
\hline
\end{tabular}

Squared figures represent top values of affinities (See text).
Total diversities are coincident with those observed in a dry zone, exhibiting their highest values in July through August and September to October. In contrast the intertidal zone reveals a low diversity nature in these 2-month duration periods which comes to its minimun degree in November-December (Tạble 3 and diagram 2).

In the first two 2-month duration periods of the year corresponding to a great anthropic interjection of public beaches, an homogeneity of diversity between both zones at relatively high levels can be observed, possibly due to the transfer of fungal species from a dry zone to an Intertidal one.

When this interjection decreases, diversity in zone $I$ also decreases while in zone $D$ keeps on steady (Table 3). Increase in diversity in Spring in the latter zone may be caused by the addition of marine organic matter which is high according to contamination signs recorded in the zone (Campos y $\mathrm{Zahr}$ 1983).

As far as number of species isolated in both zone is concerned (Diagram 3), decrease observed on 
DIAGRAM 2. Overall Shannon divensity and per zones January-December 1982.

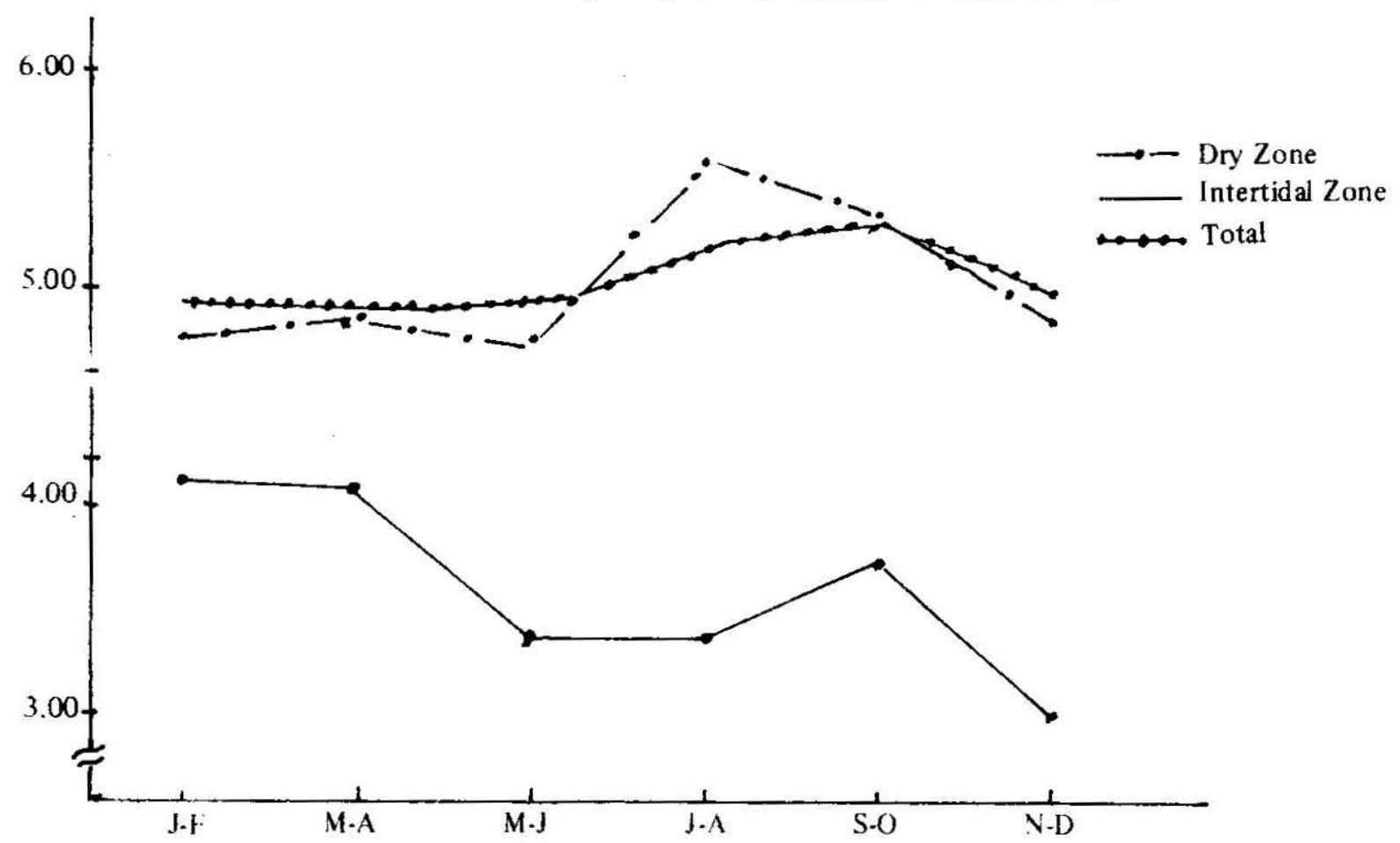

TABLE 3

Shannon diversity for both zones and totals according to two month-duration periods.

\begin{tabular}{|l|c|c|c|c|c|c|c|}
\hline \multicolumn{1}{|c|}{ Zone } & J-F & M-A & M-J & J-A & S-O & N-D & $\begin{array}{c}\text { Average } \\
\text { diversity }\end{array}$ \\
\hline Intertidal & 4.073 & 4.027 & 3.352 & 3.380 & 3.714 & 2.988 & 3.589 \\
Dry & 4.759 & 4.822 & 4.772 & 5.581 & 5.298 & 4.822 & 5.009 \\
\hline Total & 4.876 & 4.849 & 4.900 & 5.190 & 5.236 & 4.972 & 5.004 \\
\hline
\end{tabular}

the onset of Winter (May-June) can be due to high surf occurring in this period and to rains which perform a washing-away of sand, sweeping a great deal of fungal propagules into the sea.

Keratinophilic fungi in zones I and D exhibit distinct fluctuations whereas keratinolytic ones come up as a more steady group in both zones (Diagram 4). Keratinophilic fungi show a more precise response to changes in environment in their behavior as primary colonizers possibly because of the varied nutritious contribution where keratin left in situ by man, some animals and birds cannot be omitted.

The constant occurrence of a group of genera and species during every isolation process carried out throughout a vear leads us to think that keratin is not selected accidentally by keratinophilic fungi as a surviving substrate but rather as a valid alternative to the absence or decrease of other more profitable nutritious sources; adaptation to keratin would not represent a different metabolic means for these fungi but a highly selective habitat for some genera such as Penicillium. Aspergillus, Cladosporium, Acremonium, Ulocladium. Scopulariopsis, Ochroconis, Mucor, Fusarium, Alternaria, etc. (Table 1).

Thornton (1956) comes to the conclusion that in undisturbed soils, a small number of soil- 


\section{I A G R A M 3}

Number of fungal propagules per two month's duration, isolated on hair bait from January-December 1982.

Total species and per zones

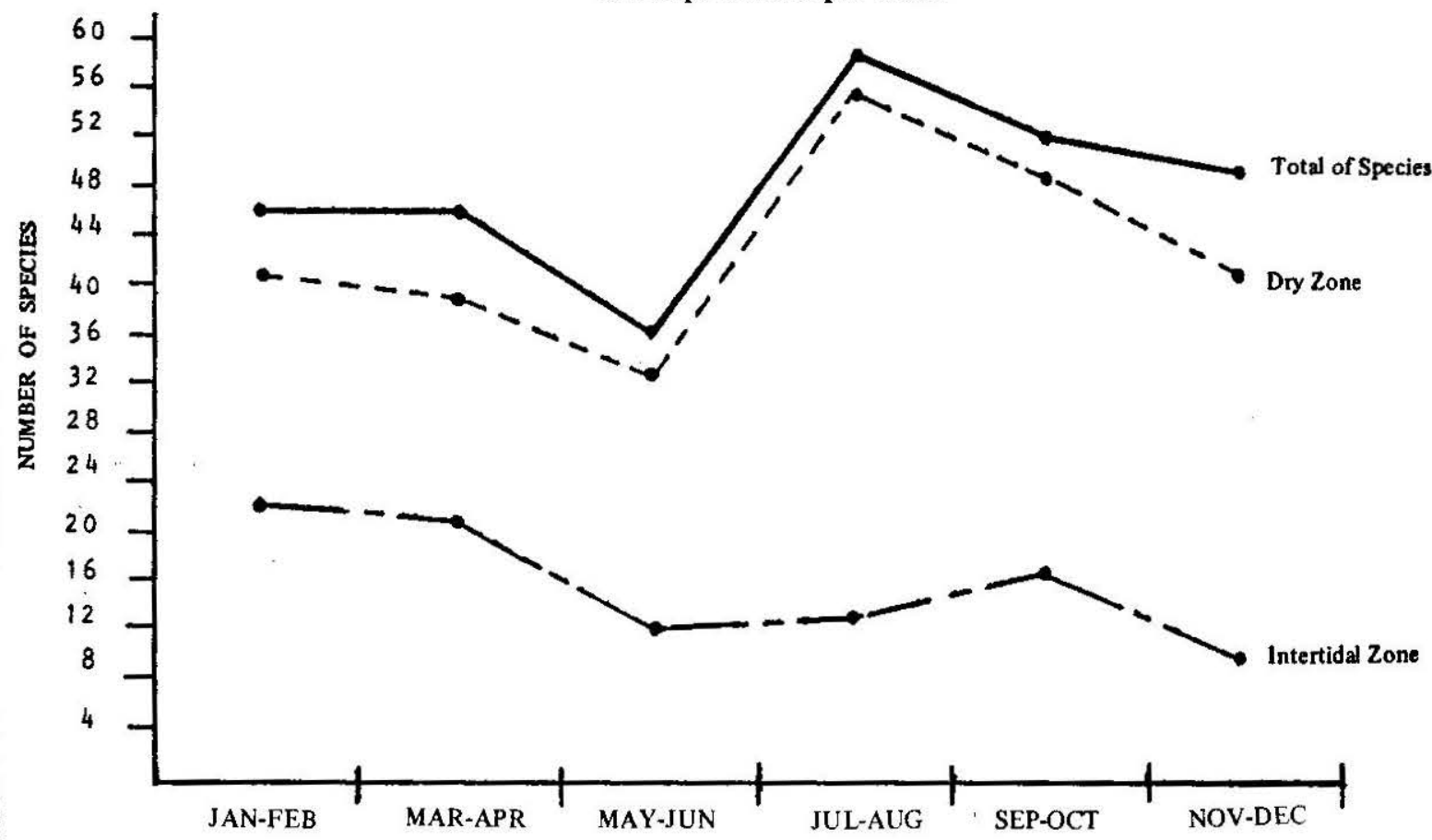

\section{DIAGRAM 4}

Overall two month-duration presence of keratinophilic-keratinolytic fungal species in total,and per Zones (I. D.)

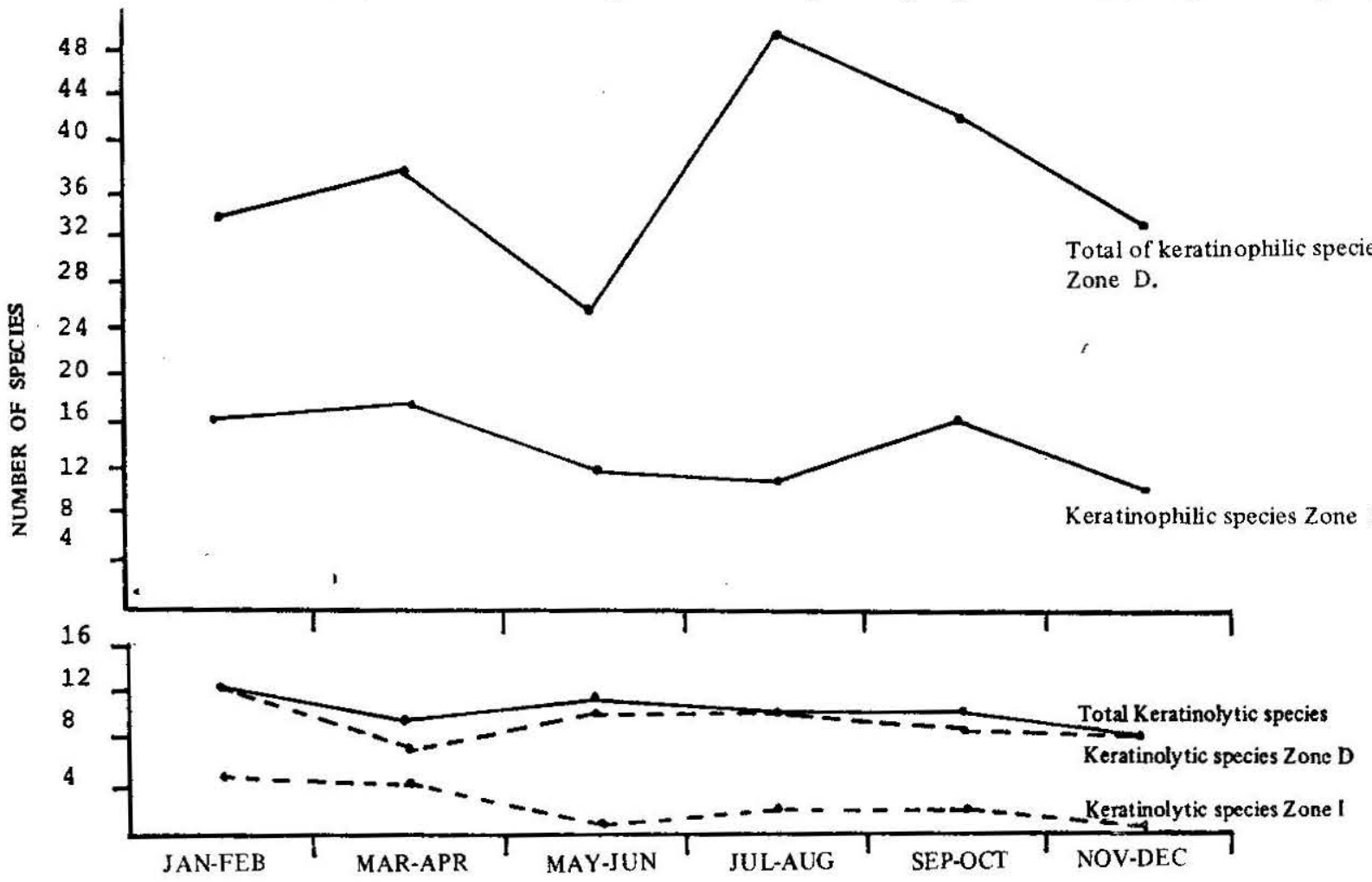


inhabiting fungal species "assume dominance" as a result of this particular, favourable condition what has been corroborated later by many other investigators (Christensen 1981).

However in our survey, Penicillium spinulosum, Penicillium aurantiogriseum and Acremonium potronii in zone I and Aspergillus ustus and Penicillium spinulosum in zone $\mathrm{D}$ exhibit a distinct dominance throughout the year, being unaffected by soil removal that takes place mainly from December through April which means a biocenotic equilibrium that suggests to consider them as species integrating beach mycota. This makes evident the importance of these genera in environment as well as the natural selectivity by the keratinic substrate.

Our results obtained by the hair bait and the dilution plate cannot be compared to those got by some workers (Dabrowa et al. 1964; Kishimoto and Baker 1969; Bergen and Wagner-Merner 1977; Esterre and Agis 1983) due to the yearly continuity of our sampling and because in literature. reference kertinic bait was only used to attain the most qualitative details without confronting in with other tech. niques.

DIAGRAM 5. Succession (averaged) in laboratory of the most frequent keratinophilic-keratinolytic fungi.

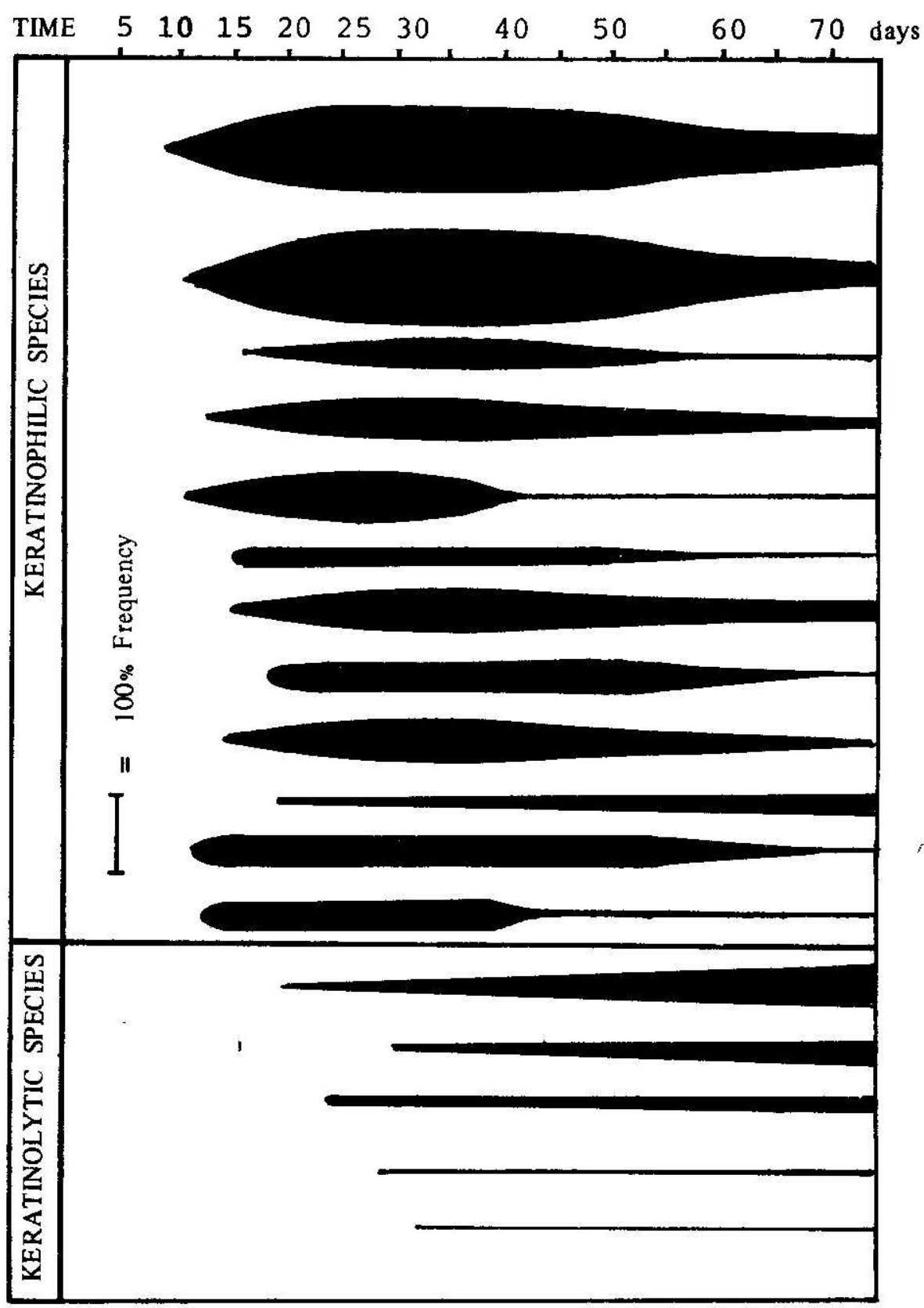

GENERA

ASPERGILLUS

PENICILLIUM

FUSARIUM

BOTRYOTRICHUM

ACREMONIUM

ALTERNARIA

OCHROCONIS

MONODICTYS

MYCELIA WITHOUT FRUCTIFICATIONS

CHAETOMIUM

ULOCLADIUM

CLADOSPORIUM

CHRYSOSPORIUM

TRHICHOPHYTON

SCOPULARIOPSIS

MALBRANCHEA

MICROSPORUM 
Number and variety of keratinolytic species gathered by Vanbreuseghem method (1952) is quite significant in our isolation techniques (see asterisks in Table 1). Kishimoto and Baker (1969) isolated representatives of the three biological categories of dermatophytes (geo-zoo and anthropophilic) among them $\mathbf{M}$. gypseum, M. canis, T. mentagrophytes, T. nubrum and E. flgccosum, surely due to the high population density existing during all of the sampling period in a geographical place (Hawaii) that allows a constant attendance of people as a result of nice climatic conditions (tropical climate). Dabrowa et al. (1964) isolate solely T. terrestre in California beaches (subtropical climate).

By using Orr's technique (1969), Todaro (1978 a, b) records different keratinolytic genera in Sicily beaches (ltaly), Chrysosporium, Arthro. derma, Auxarthron together with geophilic and zoophilic dermatophytes (M. gypseum, M. vanbreuseghemii, T. terrestre); Bergen and Wagner-Merner (1977) do not isolate dermatophytes nor keratinolytic fungi by the same methodology, possibly due to techniques employed in survey. Criseo et al. (1982) isolate solely two species of the genus Chrysosporium and an Arthroderma species in beaches in the south of Italy, while Esterre and Agis (1983), isolate only $\mathbf{M}$. gypseum in Guadaloupe beaches (France). In India, Deshmukh and Agrawal (1983) isolate M. gypseum, T. mentagrophytes and some species of the genus Chrysosporium.

Seemingly based on literature references, there is not a distinct relation between methodolagical changes and the number of isolated keratinolytic species, they rather seem to depend on several ecologic factors such as: a) human or animal population density of the study beach resulting from keratinic contribution and addition of anthropophilic and zoophilic fungal species left in situ by scaling, b) alloctonous contribution of fecal organic matter detected in littoral waters of our beach. In this respect Todaro (1978 b) states that fungal isolation percentage of beaches must be closely related to parameters of hygiene and human crowding of the coast line, the lat ter decreasing as long as they become far from urban areas, $c$ ) changes in temperature occurring during the year in open beaches and without a forest cover as in our beach (Table 4) can restrict the growth of certain fungi or promote that of thermophilic or thermotolerant species, d) constant humidity and drying of sands and e) different environmental factors.

Environmental factors considered in our survey include solely $\mathrm{pH}$ salinity and temperature avẹrages (Table 4).

The acid $\mathrm{pH}$ detected in both zones does not display any considerable changes over the period of one year. The constant acidity promotes the development and survival of most keratinophiliclytic fungal communities (Böhme and Ziegler 1969). Annual average salinity reveals that fungi in zone I become subject to a greater chloride concentration, in a logical response to a steady wave activity. a feature that can contribute to distribution and survival of some fungi (Lee and Baker 1972). Fungi capable of withstanding degrees of salìnity can take advantage of environment more effectively than those sensible to chloride. We cannot assume that every fungi isolated in our survey is salt-tolerant to a greater or lesser extent; low concentrations of $\mathrm{NaCl}$ do not seem to be an obstacle for most of isolated species. Kane and Fisher (1975) point out that $\mathrm{NaCl}$ does not restrict growth of geophilic and zoophilic dermatophytes especially to normal sea water concentrations and that $T$. mentagrophytes and $T$. terrestre are the most tolerant ones, the former being stimulated to produce macroconidia by the $\mathrm{NaCl}$ presence (Kane and Fisher 1973). Anderson (1979) thinks that salinity range of sea water is not a kind of factor that may affect survival of T. mentagrophytes and M. gypseum.

\section{TABLE 4}

Average values of main environmental parameters

\begin{tabular}{|l|c|c|}
\hline & Zone D & Zone I \\
\hline pH & 6,18 & 5,92 \\
Salinity & $0,133 \%$ & $0,191 \%$ \\
Temperature: & $25^{\circ} \mathrm{C}$ & $17^{\circ} \mathrm{C}$ \\
- Spring-Summer & $20^{\circ} \mathrm{C}$ & $15.5^{\circ} \mathrm{C}$ \\
Maximum & $\begin{array}{c}44^{\circ} \mathrm{C} \\
\text { (December) }\end{array}$ & $\begin{array}{c}12^{\circ} \mathrm{C} \\
\text { (May) }\end{array}$ \\
\hline
\end{tabular}

Temperature of sand in both zones exhibited slightly marked stationary fluctuations because of latitude and influence of sea and coast line zone (Table 4). Ranges recorded favor the growth of mesophilic and thermotolerant fungi especially Aspergillus, yet we fail to detect any proper thermophilic fungus.

The every 2-month occurrence of most frequent genera (keratinophilic and keratinolytic ones) along with their coefficients of abundance are shown in Table 1.

The genus Aspergillus which is represented throughout the year by a high number of species exhibits percentages of $32.5 \%$ in zone I and $17.7 \%$ in zone D. A. ustus has one of the highest coefficients of abundance of the genus and the fungal community in zone $D$ and is possibly transferred to zone I by people attending the beach from February through April. In spite of its appearing in this zone the rest of the year, it is not so frequent as it by this time which shows that its habitat is really zone D; this is not true in the case of Penicillium spinulosum 
which is highly predominant in both zones all the year through, indicating that its habitat comprises the overall beach area.

Penicillium, the second highly significant genus in our survey with percentages of $14.5 \%$ in zone I and $16.3 \%$ in zone $D$ has not been studied in this environment at a species level in the literature references. Criseo et al. (1982) report a $20 \%$ for genus Aspergillus and $13 \%$ for Penicillium, which are coincident with our results in zone D $(34.6 \%$ for both genera). Entities comprising these genera are common soil species inhabiting in decaying vegetal substrata and in a countless list of various environments among which it is worth to mention sandpiles used in children playgrounds in urban areas (Dominik et al. 1973. Filipello and Luppi 1982). High prevalence of these two genera throughout the year (Tables 1 and 6) indicates not only an active role in cellulose decomposition in the environment but also that its questioned and restricted enzymatic activity as regards keratin is not a sufficient condition to discard the parallel ecological task that these fungi fulfill on it. This fact given so little attention is worth to be considered actually more seriously.

With reference to comparison of the two techniques employed (H.B. and D.P.) it can be observed: a) a $37 \%$ coincidence in species detected by both techniques, displaying a Jaccard's coefficient of affinity of only 0.38 . This indicates the remarkable difference of both techniques in species detection, b) dilution method detects merely $51 \%$ of species obtained by both techniques, whereas hair-bait achieves $83.3 \%$, c) coincidence with transitory presence level is $60 \%$ among species detected by both methods, a percentage got mainly with constant and sporadic species, d) hair-bait technique allows a more natural detection due to the fact that arrangement of transitory presence level from lower to higher is $5: 3: 1$ whereas in plate dilution is $8: 1: 2$, e) dilution plate technique fails to detect a $34 \%$ of species designated as constant or frequent by the hair-bait method. The latter, however, does detect all of the constant or frequent species by the dilution method (Table 5).

TABLE 5 Coincidence between the transitory presence level for isolated species in both techniques.

\begin{tabular}{|c|c|c|c|c|c|c|}
\hline & & \multicolumn{5}{|c|}{ DILUTION PLATE } \\
\hline & & $\begin{array}{l}\text { Species not } \\
\text { isolated }\end{array}$ & $\mathrm{e}$ & $\mathrm{F}$ & C & Total \\
\hline \multirow{2}{*}{$\begin{array}{c}\mathbf{H} \\
\mathbf{A} \\
\mathbf{I} \\
\mathrm{R}\end{array}$} & $\begin{array}{l}\text { Species not } \\
\text { Isolated }\end{array}$ & - & 14 & 1 & - & 15 \\
\hline & $\mathrm{e}$ & 41 & 12 & - & - & 53 \\
\hline \multirow{3}{*}{$\begin{array}{l}\text { B } \\
\text { A } \\
\text { I } \\
\text { T }\end{array}$} & $F$ & 13 & 10 & 4 & 1 & 28 \\
\hline & $\mathrm{C}$ & 3 & 6 & $\ldots$ & 9 , & 18 \\
\hline & Total & 57 & 42 & 5 & 10 & 114 \\
\hline
\end{tabular}

This demonstrates that first method is more sensitive besides allowing isolation of all keratinolytic species (Gymnoascaceae and Onygenaceae) either in their anamorph as well as teleomorph states such as: Aphanoascus fulvescens and its anamorph Chrysosporium keratinophilum. Aphanoascus terreus and its anamorph $\mathrm{C}$. indicum. Arthroderma quadrifidum and its anamorph Trichophyton terrestre complex. Chrysosporium merdarium, C. pannicola,
C. tropicum and its teleomorph in Aphanoascus, Chrysosporium anamorph of A. cuniculi, Gymnoascus siglierae (= Uncinocarpus reesii) and its anamorph of Malbranchea, Keratinomyces ajelloi, Microsporum gypseum-fulvum complex, Malbranchea dentritica, Myceliophthora vellerea and Trichophyton mentagrophytes var. mentagrophytes (one isolation only) were not isolated by the dilution technique employed. 
TABLE 6 Dominance and transitory presence categories in both zones

INTERTIDAL ZONE

Acremonium potronii

Penicillium aurantiogriseum

Penicillium spinulosum

Micelia without fructifications

Aspergillus ustus

Aspergillus ochraceous

Aspergillus versicolor

Acremonium breve

Cladosporium cladosporioides

Penicillium lanosum

Botry otrichum piluliferum

Fusarium equiseti

Penicillium chrysogenum

Ochroconis tshawytschae

Chrysosporium tropicum

Chrysosporium pannicola

Paecilomyces lilacinus

Trichophyton mentagrophytes
DRY ZONE
C $-\mathrm{D} \quad$ Aspergillus ustus

C-D Penicillium spinulosum

C-D Penicillium aurantiogriseum

C $-\mathrm{D}$

F-A

$\mathrm{F}-\mathrm{A}$

F-A

F-A

F-A

$\mathrm{F}-\mathrm{A}$

$\mathrm{F}-\mathrm{a}$

$\mathrm{F}-\mathrm{a}$

F-a

$\mathrm{F}-\mathrm{a}$

$a-e$

a-e

a-e

a-e

Penicillium lanosum

Aspergillus versicolor

Mucor hiemal is

Chrysosporium pannicola

Aspergillus niger
C-D

C-D

C-A

$\mathrm{C}-\mathrm{A}$

$\mathrm{C}-\mathrm{A}$

$\mathrm{C}-\mathrm{A}$

$\mathrm{C}-\mathrm{A}$

C-A

C-A

C-A

C-A

$\mathrm{C}-\mathrm{A}$

$\mathrm{C}-\mathrm{A}$

C-a

$\mathrm{C}-\mathrm{a}$

C-a

F-A

$\mathrm{F}-\mathrm{A}$

F-a

$\mathrm{F}-\mathrm{a}$

Aspergillus repens

$\mathrm{F}-\mathrm{a}$

Chrysosporium keratinophilum and his

teleomorph Aphanoascus fulvescens

F-a

C. tropicum and his teleomorph

Aphanoascus sp.

F-a

Chaetomium murorum

F-a

Fusarium equiseti

F-a

F. oxysporum :

$F-a$

Scopulariopsis brevicaulis

F-a

Trichophyton terrestre complex

$\mathrm{F}-\mathrm{a}$

T. mentagrophytes

e-a

Keratinomyces ajelloi

e-a

Microsporum gypseum-fulvum complex 
As to transitory presence of the 18 steady species at a total level, 16 of them appear under the same condition in the dry zone and only 3 in the intertidal zone. Two constant species at a total level, P. aurantiogriseum and A.potronii, alternate their presence between both zones.

Highest levels of dominance and transitory presence (categories $\mathrm{C}-\mathrm{D}, \mathrm{C}-\mathrm{A}, \mathrm{C}-\mathrm{a}, \mathrm{F}-\mathrm{A}$ ) are made up by ubiquitary fungi of a marked keratinophilic activities (Table 6). Keratinolytic fungi themselves, along with a considerable number of cosmopolitan fungi make up solely the lowest levels $(\mathrm{F}-\mathrm{a}$, e . a) in both zones, that is they sometimes reach a satisfactory occurrence range in time yet showing a low dominance (e) with each appearance, differing from the former group in just lesser dominance upon isolation, which fact corroborates their task as secondary colonizers. Among the main fungi we can mention: Chrysosporium keratinophilum, C. tropicum, C. pannicola, C. indicum, Scopulariopsis bevicaulis, Paecilomyces lilacinus, Chaetomium murorum. Trichophyton terrestre, Keratinomyces ajelloi and Microsporum gypseum - fulvum complex.
All fungi growing on hair developed actively on that surface yielding a generous fructification such as to make it possible, in most cases, to recog. naize easily their characteristics as genera and species. So-called keratinophilic fungi in this work are not unique representatives of this particular habitat but share different degrading activities in nature.

Keratinolytic activity of these fungi has been reported in some genera (English 1965; Filinello and Mosca 1980-81, Domsch and Gams 1970; Domsch et al. 1980), but there is no clear information available about their actual properties to destroy the substratum either partially or totally. Many of them lack keratinase and merely degrade gradually the protein matrix of hair, its cut, the soluble elements covering it on its surface or those acquired by adsorption when hair becomes mixed with sand.

In spite of the fact that sucession can only be studied by applying several techniques that allow results approximate to the reality of the habitat, we just employed surface invasion of hair in time, in zone $\mathrm{D}$. as an indicative sign of a primary and

TABLE 7 Pathogenic or potencially pathogenic fungi isolated during the period JanuaryDecember 1982.

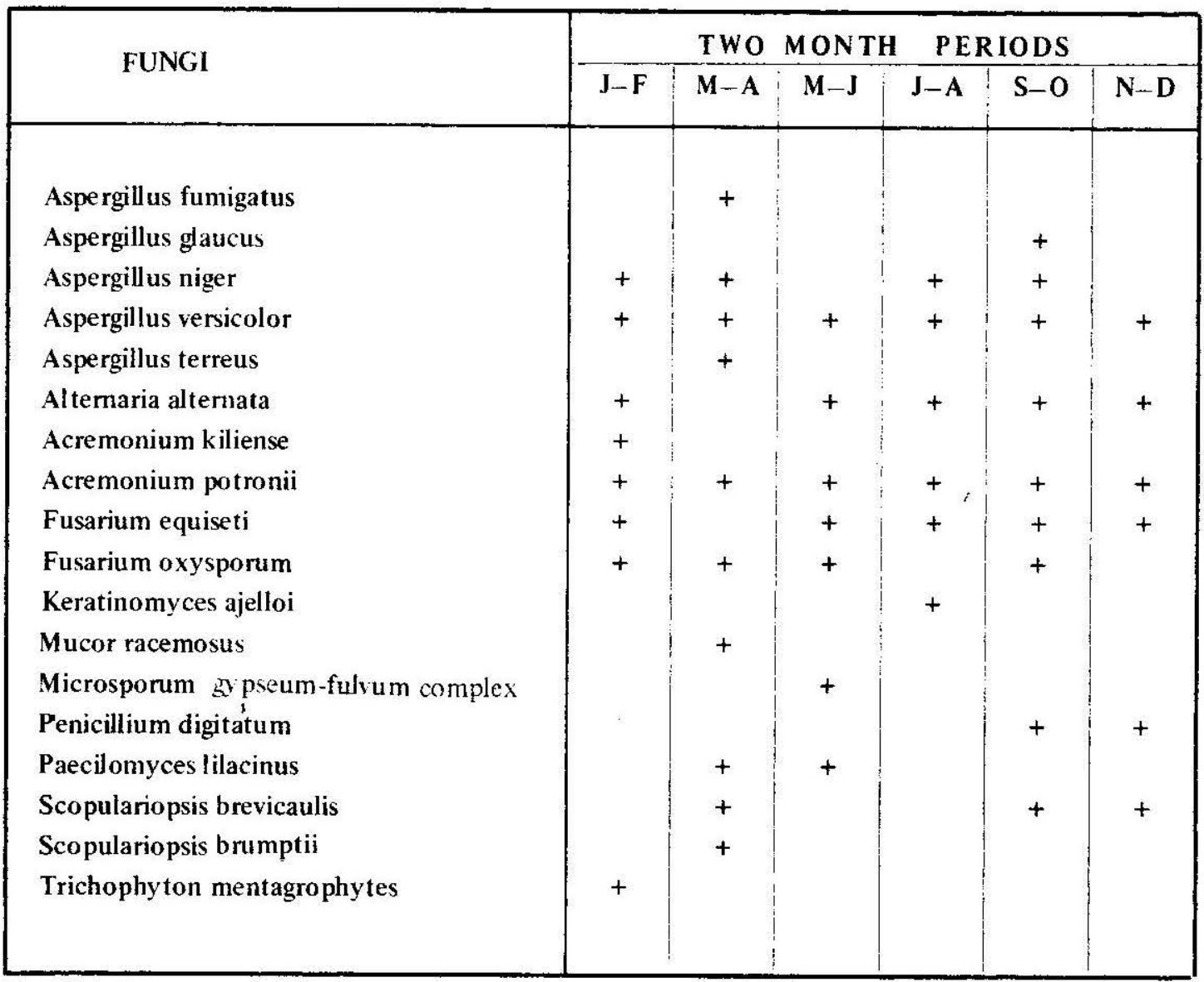


secondary colonization. In the case of keratino. philic fungi, particular degrading properties of the latter on the different types of keratin were not specifically studied here even though in some species they may ultimately look like keratinolytic fungi. It reflects, in general, succession correlated to sequence of progressive use of main organic constituents of hair, from simplest to most complex, in a manner similar to pattern studied bv Garrett (1963), in decaying vegetal substrata. Table 1 shows behavior of both categories (keratinophilic-lytic) as primary and secondary colonizers in the laboratory, emphasizing that the former ones invade substratum from the seventh through the eighteenth day and the latter from the twentieth through the thirtieth day, respectively, without making seasonal distinctions.

Genera Aspergillus, Penicillium, Acremonium, Ochroconis and Botryotrichum, in decreasing order, are primary colonizers of the most frequent occurrence in time (over 50\%). Chrysosporium. Trichophyton and Scopulariopsis are main secondary colonizers.

A total of 18 potentially pathogenic or pathogenic species were isolated during the sampling period in both zones (Table 7), most of them in warm months when influx of people going to the beach is very high.

A small group of pathogenic fungi such as M. gypseum, K. ajelloi, T. mentagrophytes, S. brevicaulis, S. brumptii, F. oxysporum, in capable of producing damages to skin, nails and cornea of man and animal. $\mathbf{M}$. gypseum and $\mathbf{K}$. ajelloi are the most frequently-occurring geophilic dermatophytes: the former is responsible at present for an increase in contingency of dermatophytes while the latter rarely causes damage to man (Alvare $z$ and Bracalenti 1984).

Conidia and mycelia of $T$. mentagrophytes can survive away from their natural biotype and have been frequently isolated from different kinds of soils containing various keratinic substrata competing with them as truly saprophytes (Mc Ginnis and Hilger 1972, De Vroey 1970). This ability to survive and adapt to terrestrial like makes it possible to identify it as one of the zoophilic dermatophytes most easily adaptable to soils and this fact leads us to think that distribution of this species is not only subject to animal influence but also to anthropic factors.

Scopulariopsis brevicaulis, S. brumptii and F. oxysporum are species isolated frequently in onychomycosis and keratomycosis all over the world as well as in our country (Zaror et al. 1982. Piontelli and Toro, unpublished data).

Some species of Aspergillus, Alternaria, Mucor, Penicillium and Paecilomyces are normal integral entities of anemophila mycota all over the world and their propagules represent etiological agents of cutaneous or systemic mycoses usually in patients suffering from weakening diseases or else they account for asthmatic picture in hypersensitive persons. Their feature as opportunist fungi and their adaptability to environment must make us think that they convey not only an ecological interest but also that their occurrence in beaches means a significant reservoir of pathogenic fungi for man.

\section{CONCLUSIONS}

We must be careful about those conclusions, which we have come to after examining data got in the laboratory, and which are concerned with events occurring in a natural habitat, Nevertheless, diversity of species collected in the mycota of marine public beaches by means of reliable techniques makes it possible for us to set forth some comments.

Some species detected in our survey and which exhibit a wide geographical distribution are not only similar to fungal communities from public beaches in other parts of the world but they are also present in other types of soils with or without a vegetal cover, such as: deserts, Grassland, forest, tundra, etc. (Christensen, 1981). This taxonomic similarity reveals that most of these microfungi are not restricted to a particular habitat but that they may become adapted, in spite of the selective pressure of habitat, to organic substrata contributed by different flora or fauna. This is the particular case of fungi herein referred to as keratinophilic.

A more restrictive group of species depend more on the specific kind of substratum than on the overall habitat. This is the case with keratinolytic fungi themselves.

The hair bait technique allows a better selectivity in the isolation of species in our survey and in this kind of soil. overcoming qualitatively and quantitatively to the plate dilution technique, especially in keratinolytic fungi. This demonstrated selectivity would be better if the search of species growing up on hair by means of a visual technique could be performed with greater care and constancy in time.

Dry zone shows a higher equilibrium of mycota than the intertidal zone in the course of a year. The number of species in both zones keeps on relatively constant 'over a calendar year, the highest relative abundance occurring in Spring and the lowest in Winter, keratinophilic fungi being the most fluctuating groups and keratinolytic fungi the most stable ones. The former play, in general, the part of primary colonizers making up the highest levels of dominance and transitory presence whereas the lat ter act as secondary colonizers with the lowest levels.

Genera Penicillium and Aspergillus here represented by many sympatric species, creates in habitat competition problems and the formulation of interesting ecological principles of a competitive exclusion. This ability becomes affected by many edaphic and seasonal factors, among which the effects of temperature must not be discarded in this kind of soil, since they may influence considerably on the ability of competition due to substrata present mainly among these species or in others (Widden 1984), this is observed in abundance seasonals coefficients of Aspergillus ustus, Penicillium spinulosum and $P$. aurantiogriseum.

Notwithstanding the fact that our methodology 
did not aim to the isolation of pathogenic fungi, we think that with the help of selective techniques, low occurrence of $\mathbf{T}$. mentagrophytes and $\mathbf{M}$. gypseum and other dermatophytes substantially increase in our processes of isolation. "Our results make it possible to consider public beaches as a source of contagion and transmission of certain fungal agents that may cause mycotic diseases in man and animals.
Keratin, its components and the elements covering its organic structures, represent an energetic source widely spread over nature; its use made by microfungi present in these soils is not only significant as a reservoir of pathogenic fungi but it must lead us to think on the possibility carrying out some intensive and thorough studies on the mycogeography of these microorganisms.

\section{BI BLIOGRAPHY}

Anderson H.J. (1979) In vitro survival of human pathogenic fungi in seaw ater. Sabouraudia. 17:1 12 .

Alvarez, D. and Bracalenti, B.C. de (1984) Aislaniento de cepas queratinolíticas con modificación del anzuelo queratinoso. Boletín Mlcológico. 2: 1-4.

Baylet, R., Delage, A. and Lauraire, C.M. (1981) Mycologie des tonds sableux en provenance des etangs littoraux mediterraneens utilises pour l'amenagement d'aires de jeux dans les campings ou colonies de vacances. Bull. Soc. Fr. Mycol. Med. 10: 269 270.

Beneke, 1.S. and Rogers, A.L. (1970) Medical mycology manual. Burges Publishing Co. Minneapolis.

Bergen. L. and Wagner-Merner, D.T. (1977) Comparative survey of fungi and potential pathogenic fungi from selected beaches in the Tampa bay area. Mycologia. 69: $299-308$.

Boiron, P. and Agis. I. (1982) litude préliminaire de la tlore levuriforme d'intérét medicale observée en milicu marin littoral en Guadeloupe. Bull. Soc. Pated. Fxot. $75: 272-278$.

Boiron, P., Agis, F, and Nguyen, V.H. (1983) l:tude de la tlore levuriforme dintérét medicale de la plage de Saint-Anne en Guadeloupe. Bull. Six: Path. lixot. $76: 351 \cdot 356$.

Böhme, H. and Ziegler, H. (1969) The distribution of geophilic dermatophytes and other keratinophitic fungi in relation to the $\mathrm{pH}$ of the soil. Mycopath. Mycol. Appl. 38: $247-256$.

Campos. V. and Zahr, M. (1984) Istudio estacional sobre contaminación microbiológica del agua en la bahia de Valparaiso. (In press).

Caretta, G. (1978) L inquinamento delie spiagge. Riv. Parassitol. $39: 57-70$.

(7ristensen, M. (1981) Species diversity and dominance in fungal communities. In Wicklow. D. and Carrol. G. (Fdi1.) The fungal Community. Chapter 12. Marcet Dekker. Inc. New lork and Basel.

Couke, B. Phaff, J., Miller. N.. Shifrine. M. and Knapp, 1. (1960) Yeast in polluted Water and sewage. Mycologia 52: $210-230$.
Criseo, G., lozzo, G., Pernice, L. and Bruno, L. (1982) Indagine e diagnosi micologica di miceti isolati su un tratto del litorale tirrenico della provincia di Catanzaro (Calabria) Quaderni Sclavo Diagn. 18: 148-155.

Dabrowa, N.. Landau, J.W., Newcomer, V.D. and Plunkett, O.A. (1964) A survey of the tide washed coastai areas of southern California for fungi potentially pathogenic to man. Mycopathol. Mycol. Appl. 24: $137 \quad 150$.

Deshmukh, S.K., Agrawal, S.C. (1983) Isolation of keratinophilic fungi from coastal habitats of Goa (India) Kovaka 11:53-54.

Dominik, T., Ihnatowicz. A., Kopylow. H. and Mietkiewski, R. (1973) Mycotlore of sand boxes in kindergardens in Szczecin. Ekol. Pol. 21: $901-923$.

Domsch, K.H. and Gams, W. (1970) Pilze aus Agrarböden. Gustav Fischer, Stuttgart

Domsch, K.H., Gams, W. and Traute-Heidi Anderson (1980) Compendium of soil fungi. Academic Press. 1 ondon.

linglish. M.P.(1965) The saprophy tic grow th of non ke ratinophilic fungi on keratinized substrata and a comparison with keratinophilic fungi. Trans. Br. Mycol. Sos. 48: 219234 .

Isterre. P. and Agis. F. 11983) Inquetc mycologique sur le sable des plages en Guadeloupe. Bull. Soc. Mycol. Med. 12:115 119.

Filipello, V. and Luppi A.M. (1980-81) Attivita cheratinolitica in vitro di miceti isolati dalie sabbie di un arenile in un parco giochi. Alliona 24:127-131.

(1982) Mycological analisis of the sands of a box for children's play. Mycopath. 80: 43-54.

Fred, F.B. and Waksman S.A. (1928) Laboratory manual of general microbiology. Mc.Grat-Hill Inc. New York.

Garre, S.D. 11963) Soil fungi and soil tertitity. Pergamon Press. ONiord.

Kanc, I. and Fisher, J.B. (1975) The effect of sodium/chloride on the srow th and morphology of dermatophy tes and some other keratolytic lungi. Can.J.Microbiol. 21: 742749 
- (1973) The influence os sodium chloride on the grow th and production of macroconidia of Trichophy. ton mentagrophytes. Mycopathol. Mycol. Appl. 50: $127 \ldots 143$

Kishimoto, R.A. and Baker, E.G. (1969) Pathogenic and potentially pathogenic tungi isolated from beach sands and selected soils of Oahu. Hawaii. Mycologia 61: $537-548$.

Lee, K.H.B. and Baker, G.E. (1972) Environment and the distribution of microfungi in a Hawaiian mangrowe swamp. Pacifi. Sci. 26: $11-19$.

Mc. Ginnis. R.M. and Hilger, H.A. (1972) Grow th of Trichophyton mentagrophytes on natural substrates. Sabouraudia. 10:230 236 .

Orr. G.F. (1969) Keratinophilic fungi isolated from soils by a modified hair bait technique. Sabouraudia. 7: $129-134$.

Paula, R.P., Purchio, A. And Gambale, W. (1983) Yeast's from beaches in the southern area of Sao Paulo state "Baixade Sautista" Brazil. Rev. Microbiol. (Sao Paulo) 14: 136-143.

Purchio. A., Paula, R.P. and Gambale, W. (1979) Isolation of Sporothrix schenkii from sea water. Rev. Micrubiol. (Sao Paulo) 10:69-71.

Sherry, J.P., Kuchma, S.R., Zarzuur, J. and Dutka, B.J. (1979) Occurrence and significance of Candida albicans in lake Ontariobathing beaches. Can. 3. Microbiol. 25: $1036 \quad 1044$.

Simard, R.1. (1971) Yeast as an indicator of pollution. Marine Pollution Bull. 2: $123 \quad 125$.

Stenderup, A. (1980) Yeast ecology. Preusser (f dit.) Medical Mycology Zbl. Bakt. Suppl. 8 Gustav Fischir. Veilag Stuttgart. $75 \quad 79$.
Thorton. R.H. (1956) liungi occurring in mixed vakwood and heath soil protiles. Trans. Br. Mycol. Soc. 39: $485-494$.

Todaro. 1· (1978 a.) Indagine sui funghi cheratinofïli come fàtori inquinanti delle spiaggie. Nota 1. Isolamenti di miceti a varia distanza dal mare. Nuovi Annali d'lgiene e Microbiol. 29: 347-352.

Todaro, fi. (1978 b.) Indagine sui funghi cheratinofili come fattore inquinanti delle spiaggie. Nota II. Risultati degli screening in 10 localitá del litorale nord di Messina. Nuovi Annali d'Igiene e Microbiol. 29: $491-498$

Vanbreuseghem, R. (1952) Tecnique biologique pour l'isolament des dermatophytes du sol. Ann. Soc. Belge. Med. Trop. 32: 173-178.

Vries, (j.A. De (1962) Keratinophilic fungi and their action. Antonie van Leeuwenhoeek. 28: $122-123$.

Vrocy, C.H. de (1970) Contribution a l'etude des dermatophytes it d'autres Gymnoscaceac. Ann. Soc. Belge. Med. Trop. 50: $1-174$.

Widden, P. (1984) The effects of temperature on competition for spruce needles among sympatric species of Trichoderma. Mycologia. 76:873-883.

Zaror, L.. lirick. P. and Moreno, M.I. (1982) Micosis ungueal por Scopulariopsis brevicaulis. Rev. Argentina de Hicologia. 5: $12-15$ 